\title{
WHO CONTROLS THE FAT CONTROLLER?
}

\section{Alistair Alcock}

Sir Topham Hatt, known to Thomas and all the other engines on the Isle of Sodor as the 'Fat Controller', started his career as a humble railway engineer. Yet he rose to become the Chairman and Chief Executive of the Railway Board. Sir Topham, of course, inhabited a simpler world than ours. He was not, for example, subject to the strictures of the Combined Code on Corporate Governance that recommends the separation of the posts of Chairman and Chief Executive. Nor was he subject to the slings and arrows faced by his recent reallife equivalent, Gerald Corbett of Railtrack, despite the appalling accident record of Sodor Railways, and of Thomas in particular. In fact there is a website pointing out that the Reverend Awdry's railway books are really elaborate apologias for capitalism, with the Fat Controller as a benign boss and the engines as recalcitrant, albeit in Thomas's case cheerful, communist workers. ${ }^{1}$

One might have expected that the collapse of communism and the apparent triumph of global capitalism would make life easier for the Sir Tophams. However, I am sure Gerald Corbett and many other directors will vouch that criticism of the boards of leading public companies has never been fiercer. It is as though, realising that it is impossible to get advanced democracies to vote against capitalism, its enemies have turned their attention to undermining its principal institution, the publicly quoted company. This assault has consisted of two not entirely compatible attacks.

1. Directors are out to line their own pockets, through remuneration and other benefits, that in no way reflect the returns made for their ultimate paymasters, the shareholders.

2. Directors only consider the interests of those ultimate paymasters, when, given the sheer power they have over modern economies, they should be balancing the interests of all stakeholders, employees, creditors, suppliers, customers, shareholders, local communities, even the environment at large.

These, of course, are not new issues. Looking at the first criticism - In one railway case of $1854,{ }^{2}$ the courts took a hard line against directors involved in

\footnotetext{
* Professor of Law at Buckingham University.

${ }^{1}$ Thomas J Clark's site at www.angelfire.com/hi2/goalie/Tommycommy.html.

${ }^{2}$ Aberdeen Railway Co v Blaikie [1843-60] All ER 249.
} 


\section{THE DENNING LAW JOURNAL}

self-interested decisions. Subsequently though, they stepped back allowing shareholders to give their directors a free hand through the internal rules of the company and leaving it to Parliament to put any overriding restrictions in place ${ }^{3}$. Even now, those restrictions allow directors of UK public companies to negotiate 5 year service contracts without shareholder approval. ${ }^{4}$ As all employment contracts are highly protected, in the case of directors they lead to the seven figure pay-offs when they are removed. ${ }^{5}$ Railtrack's shareholders may see no money from recent developments, but the directors will.

Generous service contracts have arisen despite the Combined Code's recommendation that executive directors' remuneration be settled independently by committees of non-executive directors. It is pointed out that directors' remuneration in the UK appears to be well ahead of that on the Continent, although still behind that in the US. However, to what extent this is a reflection of more accurate disclosure required by law and encouraged by lower taxes in the US and UK rather than real underlying differentials, is hard to ascertain. ${ }^{6}$ There are now proposals to limit directors' service contracts to one year unless approved in some manner by shareholders. ${ }^{7}$ As, in the end, directors remuneration and severance terms are costs borne by shareholders, giving them full information and the final say in setting them seems the only practical restraint, short of some outdated pay policy. So in this talk I want to concentrate on the second criticism of directors which raises the question - to whom should directors be answerable?

The UK courts have laid down that a directors' duty is to act bona fide for the benefit of the company, although that benefit is to be determined in the light of the objects of the company laid out in its constitution. The benefit is generally held to be for the shareholders as a body although a company is free to adopt charitable or other objects. ${ }^{8}$ Even where its objects are purely commercial,

\footnotetext{
${ }^{3}$ Clauses an a company's Articles releasing the directors from liability have been upheld in Re City Equitable Fire Insurance Co Ltd [1925] 1 Ch 407 and Movitex Ltd v Bulfield [1988] BCLC 104 but are limited by Companies Act 1985, Part X.

${ }^{4}$ Companies Act 1985, ss 318 and 319.

${ }^{5}$ Companies Act 1985, s 316(3); For an analysis of recent payoffs, see The Guardian, $30^{\text {th }}$ August 2001.

${ }^{6}$ The recent Mannesmann pay-offs suggest that continental practices may not be as straightforward as believed until now.

${ }^{7}$ Modern Company law for a Competitive Economy: Final Report (DTI, July 2001), para 6.13 , although in other respects the proposals on self-interested transactions relax the current law.

${ }^{8}$ A company's Memorandum can contain charitable and other objects, Re Horsley \& Weight Ltd [1982] 3 All ER 1045, 1052.
} 
the courts have allowed directors a wide subjective discretion. As Bowen LJ said back in 1883 in another railway case: ${ }^{9}$

"A railway company, or the directors of the company, might send down all the porters at a railway station to have tea in the country at the expense of the company. Why should they not? It is for the directors to judge, provided it is a matter which is reasonably incidental to the carrying on of the business of the company...."

Perhaps to the relief of many here, even charitable payments to educational establishments can be reasonably incidental. ${ }^{10}$ The one notorious case where the courts did intervene was in the 1960s, Parke v Daily News. ${ }^{11}$ This involved an attempt by a board winding up the company to make extra payments as redundancy to its employees rather than return the money to the shareholders. The court held this could not be for the benefit of the company as it no longer needed any employees. There followed a public outcry and a change in the law. Directors were given a specific power to make such payments even if they were not in the interests of the company. A general duty was also imposed on directors to consider the interests of employees, albeit a duty not enforceable by those employees. $^{12}$

I remember being puzzled as a student in the 1970s, why the Daily News affair caused such a fuss. Two things struck me:

1. If, as is usual, the company had been insolvent on winding up, no one would have suggested there should be extra payments to employees at the expense of say trade creditors. Why should shareholders, who are in some respects only creditors with particularly weak contractual rights, be treated differently?

2. Imposing duties on directors to consider interests without an enforcement mechanism ironically increases their power, because this gives directors defences against interests that might otherwise have been able to enforce, ie shareholders.

However, in the UK, individual shareholders have almost no legal power to enforce their interests against the directors of publicly quoted companies. From

\footnotetext{
9 Hutton v West Cork Railway Co (1883) 23 ChD 654, 672.

${ }^{10}$ Evans v Brunner Mond \& Co Ltd [1921] 1 Ch 359.

${ }^{11}$ [1962] Ch 927.

${ }^{12}$ Companies Act 1985, ss 309 and 719.
} 


\section{THE DENNING LAW JOURNAL}

the early decision of Foss $v$ Harbottle in $1843,{ }^{13}$ through Percival $v$ Wright in $1902^{14}$ to Re Blue Arrow plc in $1987,{ }^{15}$ it has been made clear by the courts that, except in the most egregious cases, dissatisfied shareholders of such companies should not resort to law. They must either use their votes to change the management or sell their shares. Theirs is only a loose residual control. So has the wide freedom the courts have given directors left them free to pursue the stakeholder view of corporate governance, balancing the interests of employees, creditors, suppliers, customers, shareholders, local communities and the environment? ${ }^{16}$

Certainly those who passionately espouse the stakeholder view think not and they are probably right. ${ }^{17}$ Dissatisfied shareholders tend to sell their shares. That lowers the share price. To the extent that directors themselves have shares or options, this directly hits their pockets. Even where, as on the Continent, they do not, a falling share price means a rising cost of raising money from the market, and from other sources like banks as they in turn become more nervous. A company with a low share price and a concomitant high cost of capital is restricted in the investments it can afford to make and is vulnerable to takeover by its more successful competitors, which means no jobs for its directors. This is the crude discipline of the market against which the stakeholder view rebels.

That rebellion has marked up some successes in recent years. In the United States, a number of states have adopted stakeholder duties in their corporation laws. ${ }^{18}$ The courts have supported this approach by allowing directors to use poison pills to stop hostile takeover approaches being put to shareholders leaving the directors free to consider other interests, not least their self-interest in keeping their jobs. ${ }^{19}$ Following this line, the European Parliament rejected a Draft Directive earlier this year that would have outlawed such a use of poison pills across the European Union. ${ }^{20}$ Meanwhile, in the UK, the Company Law Review Steering Group looking into company law reform, also seems to have succumbed to the stakeholder (or as it terms it, the pluralist) approach. It has usefully defined this approach as believing:

\footnotetext{
${ }^{13}$ [1843] 2 Hare 461.

14 [1902] 2 Ch 421.

15 [1987] BCLC 585.

16 This is what Berle and Means predicted in The Modern Corporation and Private Property (New York: Macmillan, 1932; revised 1967).

${ }^{17}$ eg Parkinson Corporate Power and Responsibility: Issues in the Theory of Company Law (Oxford: Clarendon Press, 1993) (“Parkinson”).

18 eg Pennsylvania's Business Corporation Law of 1988 as amended by the Takeovers Act of 1990 , ss 1714 to 1721 .

${ }_{19}$ Paramount Communications Inc v Time Inc 571 A.2d 1140 (Del 1989); Unitrin v Amrican General Corp 651 A.2d 1361 (Del 1995).

$2013^{\text {th }}$ Company Law Directive.
} 


\section{THE DENNING LAW JOURNAL}

... the ultimate objective of maximising shareholder value will not achieve maximum prosperity and welfare... company law should be modified to include other objectives so that a company is required to serve a wide range of interests, not subordinate to, or as a means of achieving shareholder value... ${ }^{21}$

In other words, the stakeholder or pluralist view goes further than asking directors to consider all relevant stakeholder interests in trying to maximise the long term value of the company for shareholders. It wishes decisions benefiting those stakeholders to be taken even if it harms shareholder value, what Professor Parkinson, a keen exponent of this view and a member of the Steering Group, has dubbed 'profit sacrificing social responsibility'.

The Steering Group (a sort of unofficial Royal Commission) subsequently concluded:

"The overall objective [of UK company law] should be pluralist in the sense that companies should be run in a way which maximises overall competitiveness and wealth and welfare for all...”22

So has this stakeholder or pluralist view triumphed? Not yet. In the US, shareholders can still get poison pills lifted by threatening to vote off the directors and the courts have been reluctant to allow directors to protect themselves from such removal by current shareholders. ${ }^{23}$ In Europe the $13^{\text {th }}$ Company Law Directive may still be revived and would not in any case affect the UK Takeover Panel's firm line against defence tactics that prevent shareholders deciding on bids. And for all its rhetoric, the Company Law Review Steering Group has not accepted the pluralist view. Indeed, it proposes to replace all the current common law duties imposed on company law directors, ${ }^{24}$ with a statutory formula that includes a ferocious reaffirmation of shareholder primacy, namely:

A director of a company must in any case-

${ }^{21}$ Modern Company Law for a Competitive Economy: The Strategic Framework (DTI, Feb 1999), para 5.1.13

${ }^{22}$ Modern Company Law for a Competitive Society: Developing the Framework (DTI: March 2000), para 2.21

${ }^{23}$ Bank of New York v Irving Bank Corporation 139 Misc.2d 665 (NY Sup Ct 1988); Hilton Hotels Corporation v ITT Corporation 978 F Supp 1342 (Nev 1997)

${ }^{24}$ Draft Companies Bill, s 17 in Modern Company Law for a Competitive Economy: Final Report, Annex C. 
a. act in the way he decides, in good faith, would be most likely to promote the success of the company for the benefit of its members as a whole...; and

b. in deciding what would be most likely to promote that success, take account in good faith of all the material factors that it is practicable in the circumstances for him to identify.

This seems a much tougher duty to forward shareholders' interests than the current one imposed by the courts. There are no general overrides for charitable purposes or employees' interests unless they appear specifically in the company's constitution. Even the interests of creditors may be downgraded. ${ }^{25}$

So where have all the much vaunted stakeholder or pluralist interests gone? They have been relegated to the notes explaining 'the material factors that it is practicable in the circumstances for him to identify' and not even to the primary factors. No, stakeholders are merely included in other factors and are listed as:

a) the company's need to foster its business relationships, including those with its employees and suppliers and the customers for its products or services;

b) its need to have regard to the impact of its operations on the communities affected and on the environment;

c) its need to maintain a reputation for high standards of business conduct;

d) its need to achieve outcomes that are fair as between its members.

Notice, these 'needs' only arise to the extent that a reasonable director would consider them relevant in the circumstances to promote the success of the company for its members. They are awarded no special weighting and are certainly not given any mechanism for direct enforcement. Indeed, the drafting puts as the primary factors:

the likely consequences (short and long term) of the actions open to the director, so far as a person of care and skill would consider them relevant.

This emphasises two matters of particular concern to the Steering Group, but which are both probably current law:

\footnotetext{
${ }^{25}$ Some duty currently arises under West Mercia Safety Ltd v Dodd [1988] BCLC 250 when a director ought to have realised that insolvency was 'more likely than not'. The Steering Group have contemplated removing this and leaving an overriding duty to creditors only arising when a director ought to have realised that was 'no reasonable chance of avoiding' insolvency, the position under Insolvency Act 1986, s 214.
} 
1. directors should consider both the long as well as the short term consequences of their actions, an exhortation against 'short-termism'; and

2. directors should apply an appropriate standard of skill and care to their tasks, not just that of an educated layman. ${ }^{26}$

By emphasising these two, any statutory general duties will undoubtedly add to the bureaucracy of decision-taking in publicly quoted companies as paperwork is assembled to show that short and long term issues were carefully considered. The stakeholder issues listed in 'other factors' will no doubt add to this trend. One can imagine public company boards being flooded with special pleading from innumerable pressure groups. Whether this will improve the quality of the decisions is harder to say. What can not be made to go away are the underlying conflicts of interest that directors have to deal with. As the Steering Group starkly put it:

The interests of the shareholders and others will clash... [eg] a decision whether to close a plant with associated redundancies or to terminate a long-term supply relationship, when continuation in either case is expected to make a negative contribution to shareholder returns... In such circumstances, the law must indicate whether shareholder interests are to be regarded as overriding, or some other balance should be struck. ${ }^{27}$

However much the Steering Group may try to disguise it with warm words and phrases, it has firmly concluded that 'shareholder interests are to be regarded as overriding'.

So is the war over? I fear not. We have not seen any Government Bill to date and as the Steering Group found on a number of other reform issues, its freedom to propose sensible measures was constrained by European Directives. The experience of the $13^{\text {th }}$ Company Law Directive shows how the best laid plans can be destroyed in the European legislative process. Also, no doubt to keep those with stakeholder views like Professor Parkinson on board, the Steering Group

\footnotetext{
${ }^{26}$ The old and possibly outdated test in Re City Equitable Fire Insurance Ltd [1925] 1 Ch 407; but see Norman v Theodore Goddard [1991] BCLC 1028, 1030; Re D'Jan of London Ltd [1993] BCC 646, 648.

${ }^{27}$ Modern Company Law for a Competitive Economy: The Strategic Framework, para 5.1.15.
} 


\section{THE DENNING LAW JOURNAL}

avoided any ringing endorsement of traditional shareholder value. Its objections are dressed up as largely practical:

A few still supported a 'pluralist' approach, imposing a duty to balance the interests of relevant parties without necessarily giving priority to those of members; but none of those responses suggested a practicable means of dealing with the crucial question of how such a duty could be enforced. This is to our mind a key objection. ${ }^{28}$

This is a terribly British approach, disguising political, even moral issues as matters of practicalities. Indeed, by now you are probably wondering why I have been dragging you through this mire of company law technicalities, but behind them lurk fundamental issues of freedom, political legitimacy and the rule of law. So in the second half of this lecture I would like to take the opportunity to demonstrate to you that the stakeholder view of corporate governance is not just impractical, it is deeply immoral.

1. The stakeholder attack on the traditional shareholder value approach comes in two slightly different guises:

2. Other interests are just as vulnerable as shareholders and deserve equal consideration; and Directors of large public companies are just too powerful to be left only to consider their shareholders' interests.

The first argument starts from the point that shareholders are not in a unique position of risk. Others, like suppliers and employees, have to make 'firm specific investment' and, unless it is protected, they will be discouraged from making such investment. Bluntly, in a post-industrial society, this is nonsense. Computerisation has made most firm specific supplying easy and cheap. To the extent that satisfactory arrangements can not be secured by contract, there always remains the option of bringing the function in-house. ${ }^{29}$

The position has changed just as much for employees. The rise of the skilled 'knowledge worker' ${ }^{30}$ and the protection of employment law have made

\footnotetext{
${ }^{28}$ Modern Company Law for a Competitive Economy: Completing the Structure, para 3.5.

${ }^{29}$ As Coase pointed out in the 1930s, that is the principal justification for functions being brought within the structure of a firm; Coase 'The Nature of the Firm' in Williamson and Winters (eds), The nature of the Firm: Origins, Evolution and Development (New York: OUP, 1993).

${ }^{30}$ Drucker, Post-Capitalist Society (New York: Harper Collins, 1993) (“Drucker”).
} 


\section{THE DENNING LAW JOURNAL}

employees, at least of well-financed public companies one of the most privileged contracting groups in society. As we have seen, that is why executive directors, who have employment contracts, get such wonderful pay-offs. Employees are merely a heterogeneous private interest group, sufficient of whom may form an alliance with the directors against any other interests. Privatisation was not about finding new management or cheaper capital. The old management often remained and a stable government can always raise capital cheaper than private firms. No, it was, and still is, about breaking the restrictive practices of management and employees by cutting off the tax guarantee behind the nationalised industries and their boards. I look forward to see what Railtrack Mark 2 gets in the way of backing from the Treasury.

At this point, defenders of the stakeholder view usually point to the Japanese and German models which in their different ways incorporate employees into their governance structures. But that is only half the story. Both have depended upon a highly protected banking system providing the discipline that shareholder dissatisfaction provides in the Anglo-American model. In Japan, it can now be seen that the banks failed to exercise that discipline with disastrous consequences and in Germany, they are beginning to lose the power to do so. This hardly seems the moment to adopt such an approach even if we had developed the necessary banking arrangements to do so, which we have not.

So why does forwarding employees' interests at the expense of shareholders' still instinctively seem so moral? There still lurks the impression that, compared to honest toiling employees, shareholders are lazy good-for-nothing rentiers. In fact, shareholders in UK publicly quoted companies are largely the pension funds of, not just the privileged knowledge workers, but also the less privileged 'service workers' throughout the economy. Of course, it can be argued that things do not have to be arranged this way. Whether pensions are funded or not, pensioners remain dependent for their income on current workers. The continental pay-as-you-go tax based system could be adopted. However:

1. public expenditure pressures have already undermined that system in the UK and are now doing so elsewhere; and

2. such a system would be dependent on taxing an aging UK population. Returns on publicly quoted companies are by their nature global, incorporating returns from younger, more vibrant economies.

Could we, in any case, do without shareholders? After all, ordinary shares are only a funny form of loan, which offers no pre-determined right to any interest or capital back. They just have a claim to the residual surplus on winding up after everyone else has been paid, with dividends as discretionary payments on account. The only contractual weapon given to their holders is a degree of 


\section{THE DENNING LAW JOURNAL}

residual control in the form of a vote, in particular a vote to change the directors. Investment theorists, like Modigliani and Miller, ${ }^{31}$ would argue that it does not matter whether a company is financed by debt or shares since all they are doing is allocating the risks and returns of the underlying business of the company. The company is just an allocative vehicle. But the debt-equity structure does matter, because companies reliant on debt, have to pay interest and capital on time which increases the risk of bankruptcy, and this is not costless. Management, from its own self-interest and from emotional ties to the company and its employees, is likely to try and avoid this risk. ${ }^{32}$ The management of companies dependent on debt finance is therefore likely to reject high-risk projects and, if most companies in an economy are dependent on debt, the whole economy can become riskaverse. It was the need to issue shares to finance highly speculative railways in the $19^{\text {th }}$ Century that was the impetus behind the creation of UK company law in the first place. No - share capital is vital because in a fickle world, it is permanent, a feature that European companies, until now dependent on bank finance, are increasingly appreciating. As the Financial Times pointed out yesterday, the Government still has this problem if Railtrack Mark 2 is to get any outside funding. ${ }^{33}$

This brings me the second argument for the stakeholder view, which starts from the sheer size of the largest multinational companies. These have turnovers greater than the GDPs of some quite substantial countries. The directors of these companies are making investment decisions that affect thousands of employees, the communities that they come from, even the whole environment. Governments seem helpless in the face of such organisations as they shift capital and profits around the world. Classical economists' maintain that corporate behaviour is no more than a reflection of the popular will, expressed not through the ballot box, but via individual purchase decisions. But that seems unrealistic in the face of corporate giants like Shell, Microsoft, Nike or McDonalds.

Those holding stakeholder views point to at least three ways that the market does not operate efficiently:

1. the size and power of the established players allow them to create barriers to entry for competitors, leaving them room for manoeuvre;

2. companies have an informational advantage, eg unjustifiable claims through advertising, public relations etc.

\footnotetext{
${ }^{31}$ Modigliani and Miller, 'The Cost of Capital, Corporation Finance and the Theory of Investment' (1958) 48 American Econ Rev 261.

32 Management may fear not just a loss of employment and reputation, but personal liability under West Mercia Safetywear v Dodd or Insolvency Act 1986, s 214, see above.

${ }^{33}$ Financial Times, $8^{\text {th }}$ October 2001, Lex Column.
} 
3. externalities can be exploited, eg companies can poach trained staff or damage the environment without being made to pay.

Let us take each in turn:

1. The electronic and communications revolution have given even the largest companies far less room for manoeuvre than even twenty years ago. Look at the car industry. In Europe each country was dominated by one or two local manufacturers. Now in the UK and rapidly through the rest of Europe, no company has more than 20\% of the local market. Companies also have to be responsive to the vagaries of these markets, McDonalds on the meat it serves in India, Shell on the disposal of rigs in Northern Europe. These organisations are not quite the monoliths they first appear to be.

2. Although it is never possible to produce a level playing field in information, again the electronic and communications revolution have made things much easier for consumers. Indeed consumer and other pressure groups have been major exploiters of the internet. Governments can always help by demanding the publication of more information and that is one of the major recommendations of the UK Company Law Steering Group.

3. Externalities are also a matter for Governments to settle. For example, how can companies regulate themselves as to what land may be exploited for oil, superstores or housing. On the other hand it has to be recognised that increased regulation is often loved by major corporate players because it raises the barriers against competitors entering the market. For a passionate espousal of this view, look no further than the recent Cruickshank Reports on Banking and their attack on the proposed new financial regulation. ${ }^{34}$

Even for the largest multi-nationals, market forces are intense and can not easily be willed away. As one commentator has put it:

"The business executive who chooses voluntarily to spend until it hurts on the environment, on training, the handicapped, or on support of higher education, is likely to find that he is vulnerable

${ }^{34}$ Competition and Regulation in Financial Services: Striking the Right Balance, HM Treasury, July 1999; Competition in UK Banking: A Report to the Chancellor of the Exchequer, Stationery Office, March 2000. 
to undercutting by firms without a social conscience that, by avoiding such outlays, can supply outputs more cheaply”. ${ }^{35}$

Even Professor Parkinson at the end of his magisterial apologia for the stakeholder view was forced to admit:

"Any changes designed to increase corporate social responsiveness that are liable to add significantly to companies' costs cannot in an increasingly global marketplace be safely introduced in one country. Whether the changes are in governance structures or are measures to stimulate responsibility, or are more stringent conventional regulatory controls, they will need to apply more widely if domestic economies are not to be disadvantaged in the face of international competition. In Europe, this emphasises the importance of the social, in addition to the economic, dimension of European collaboration". ${ }^{36}$

But just think for a moment what is being said there. That is a plea for the creation of a protectionist Europe, with a tariff wall and exchange controls, aimed at allowing European companies to indulge in profit sacrificing social responsibility, just like the old Comecon businesses in the Communist bloc. All this may seem a bit far-fetched at the moment, but listen to recent outbursts from the current French Prime Minister, Lionel Jospin and think what pressures might build up if we were now to face a prolonged recession. I think the new applicants to the European Union from Eastern Europe might be surprised to find themselves re-entering a protectionist club.

Of course it can be argued that the stakeholder view does not require such extreme measures to be taken, at least to start with. A modicum of profit sacrificing social responsibility would be quite sufficient. But even that gives rise to serious difficulties. To allow it would require either:

1. directors to be given the power to consider all the various interests, which would be a massive increase in directors' discretionary power; or

2. directors are given the duty to consider such interests, which would be a massive increase in the courts' discretionary powers.

\footnotetext{
35 Baumol '(Almost Perfect Competition (Contestability) and Business Ethics' in Baumol and Blackman (eds), Perfect Markets and Easy Virtue: Business Ethics and the Invisible Hand (Cambridge, Mass: Blackwell, 1991), p 53.

${ }^{36}$ Parkinson p 433.
} 


\title{
THE DENNING LAW JOURNAL
}

Either way, political power and decision making would be transferred to nonpoliticians, in the words of the Steering Group, 'turning company directors from business decision-makers into moral, political or economic arbiters' ${ }^{37}$ Can you imagine how dangerous and anti-democratic this could be? As has been put most forcibly by Levitt:

\begin{abstract}
"What we have, then, is the frightening spectacle of a powerful economic functional group (ie management) whose future and perception are shaped in a tight materialistic context of money and things but which imposes its narrow ideas about a broad spectrum of unrelated non-economic subjects on the mass of man and society”. ${ }^{38}$
\end{abstract}

If you think that is an exaggeration, think of the baleful effect the involvement of businessmen has had on education in this country. And what sort of political legitimacy would this new 'nomenclatura' have?

Professor Parkinson and others proposing the stakeholder view suggest that legitimacy could be achieved with new structural checks and balances; but the only stakeholders whom it is easy to incorporate into corporate governance are employees. Parkinson himself admits that state appointees do not have a happy track record. Political interference over decades has reduced our railways to a ludicrously crash-averse, investment starved wreck. Who is going to stand up and point out to Railtrack Mark 2 that the railways can afford to lose dozens of passenger lives a year and still be the safest form of transport in the UK. As for other stakeholders, like suppliers and customers, they can hardly be incorporated for fear of creating multiple restrictive practices and conflicts of interest. This leaves the employees which brings us back to the dangers of incorporating their interests which I have already described.

So what are we left with overall? The proponents of the stakeholder view claim that it offers a $3^{\text {rd }}$ way, a form of communitarianism. Directors would be required to temper the financial success of their companies with policies to protect employees, suppliers and their communities and to respond to the various demands of environmentalists. After all, even under the Steering Group's formulation of directors' duties, these are matters that directors should, where appropriate, consider. But with one important difference. Directors would still have a clear overriding goal, shareholder value. As Drucker has pointed out, having a single focus is vital for the success of an organisation:

\footnotetext{
${ }^{37}$ Modern Company Law for a Competitive Society: Developing the Framework para 2.21 .

${ }^{38}$ Levitt, 'The Dangers of Social Responsibility' in Marshall (ed) Business and Government: The Problem of Power (Lexington: Heath, 1970) p 27.
} 


\section{THE DENNING LAW JOURNAL}

Organisations are special-purpose institutions. They are effective because they concentrate on one task. If you go to the American Lung Association and say: "Ninety per cent of all adult Americans... suffer from ingrown toenails; we need your expertise in research, health education and prevention to stamp out this dreadful scourge," you'd get the answer: "We are interested only in what lies between the hips and the shoulders."

That explains why the American Lung Association or the American Heart Association or any other organisation in the health field gets results... Only a clear, focused and common mission can hold the organisation together and enable it to produce results. ${ }^{39}$

Communitarians find such single-purposedness uncomfortable. They dream of a quiet, orderly, dare I say static world, the sort of world described in the Reverend Awdry's railway books. The Isle of Sodor exists somewhere off the coast in Never-Never-Land, free from global forces - technological change never threatens steam trains, farmers somehow survive keeping the odd cow or pig, the Fat Controller never faces difficult pricing or investment decisions, like scrapping Thomas. There is never a mention of death or taxation.

Of course, in the real world, decisions on the provision and funding of public services, on employee security, protection of local communities, land use and other environmental issues can not be avoided. But they must be taken by democratically elected politicians. It is their job to present issues to the electorate and create a framework of laws and taxes within which companies then have to operate. They have got to stop trying to palm off these decision onto others and hide them away from democratic comeback. Already it is too easy to use the European Union under the Treaty of Rome and the courts under the European Convention of Human Rights. Politicians bemoan the declining turn out at elections, but what is the point of voting if the critical decisions seem to made elsewhere.

This evening we have traveled a long way from questions of directors' remuneration and the technical drafting of their duties. May I leave you, however, with a nightmare scenario of what might happen if the stakeholder view were to triumph.

If the stakeholder view is adopted, boards of publicly quoted companies, confronted with a range of conflicting interests, will start to take profitsacrificing decisions to meet some of them. This and the concomitant lack of focus of their businesses will slowly render them less competitive internationally. Businessmen will increasingly call for tariffs and/or subsidies to survive. This will put them into the hands of government which in return, will make random

${ }^{39}$ Drucker, p 53. 
demands on their companies to support governmental pet projects. Corporate well-being will become less a matter of successful competition within a framework of laws and more a competition for special privileges from government, privileges that, as Railtrack and its shareholders discovered, can be withdrawn at any time. This is a competition for survival that medieval barons would have recognised, or indeed more recently, industrialists in Nazi Germany. This is not cosy communitarianism, it is corporate feudalism. The United Kingdom took three centuries and at least one civil war dismantling such arrangements. The United States took a further two civil wars.

I am not saying that corporate feudalism can never work. It has allowed a number of Asian countries to catch up economically and it could be argued that Britain reverted to it to survive two world wars. But it is hardly a credible approach for a leading peace-time economy and even if it were, the price in terms of personal and business freedom is, in my opinion, far too high.

By now I need hardly declare my colours, but lest any of you remain in doubt. I am not a cultural relativist, nor do I believe that you can go round borrowing bits and pieces from other systems. I am a fanatical believer in western liberal democracy, particularly as practised in Anglo-Saxon countries not because it promotes economic wealth, although I think it does, but because, with all its manifold imperfections, it promotes freedom and transparency. Stakeholder views are for me an anathema. They break down a critical separation of powers, not the usual separation of executive, legislature and judiciary, which has never been clearly accepted in this country, but the much more vital one between government and business. If the great corporations can not be dealt with on a fair arms-length basis, what hope is there for us mere mortals?

On the Isle of Sodor, we never get to know who controls the Fat Controller, but I pray that here on the mainland, it remains, however loosely, the shareholders. 